\title{
Explicating Industrial Brand Equity in Liberalized Energy Market in Egypt
}

Sarah Osama Abd El Rahman Adam

Teaching assistant- Business administration- faculty of commerce-Cairo University sarah_osama@foc.cu.edu.eg

Cell phone: 01006768310

\begin{abstract}
The body of research within industrial context still lags far behind our knowledge of branding in consumer context as most of research discussions have been developed in consumer context. In particular, the role of specific brand associations in liberalized energy brands is still to a large extent largely undetermined. Moreover, previous studies over rely on tangible and rational attributes which alone cannot explain fully the logic behind purchase decisions in B2B context. Therefore, this paper is set to investigate the industrial brand equity in Liberalized Energy Market in Egypt for companies operating in the Joint sector. Up to the researchers 'knowledge, this is the first trial to investigate a comprehensive model for industrial brand equity in liberalized Energy market context. As well as, the mediating role of trust between brand associations and brand loyalty will be considered.
\end{abstract}

Keywords Liberalized Energy market, Industrial brand equity, Brand associations, Brand performance, industrial brand image, Trust, Brand loyalty. 


\section{Introduction}

In the recent decade, deregulation in energy market has opened previously monopolistic environments which in turn allow for free market competition (Hartmann and Ibanez, 2017). The various services and products provided by private supplier companies operating in liberalized energy market in Egypt includes; installation and delivery of bio-energy heating plants, drilling equipments, machines, drilling services, occupational health services, consultation services ,maintenance, introducing new technologies to the well servicing field, technology equipments provision, oil field services, food supplies, offshore services, drilling rigs and platforms, provision of state-of-the-art techniques and proven technologies, lifting services, environmental services, technical services and consultation services.

Business-to-business products differentiation is fading as firms competing just on pricing and personal relationships, as a result, decreasing companies profits. As firms adoption of the cost reduction policy such as low-cost production and technology, arouse the problem and allow for minor differentiation in such markets (Alwi et al. 2016). Thus, to face such fierce competition, suppliers shift to branding through applying strategies of differentiation to implement a sustained competitive advantage (Alwi et al. 2016). In this sense, branding in industrial context is essential as it augments the industrial brand equity through: first, cash flow benefits provision to companies and increased power of the network; second, enhancing the industrial brand's identity (Beverland et al., 2007); and third, establishing brand equity through corporate brand image (Chi-Shiun et al., 2010). In response, many energy companies are concentrating on branding, seeking to improve customer loyalty in which Energy brands with brand associations more 
pleasing to customers will have the capability to impose a premium price (Hartmann and Ibanez, 2007).

Such advantages results in various scholarly research stressing on industrial brand equity and more focus on intangible aspects such as brand image (Davis et al., 2008; Van Riel et al., 2005). As branding becomes an afterthought due to high levels of complexity and intangibility in liberalized Energy Market context context in which customization is frequently low owing to two reasons; first, the product (fuel) is the same with minimum variation in the quality and second, packaging is naturally not possible in oil and gas business. Hence, little differentiation exists in the type of product they manufacture, with little chance of being unique (Alwi et al. 2016). Thus, private suppliers can achieve brand equity by establishing associations that are; strong, favorable and unique in the customers mind which is then interpreted into loyal customers.

Therefore, this research has three main objectives. First, to understand customer companies in the joint sector perceptions toward industrial brand associations of private suppliers in Liberalized Energy Market context across engineers, accountants and geologists in the buying center. Second, based on "The Social exchange theory" developed by (Blau, 1964) we formulate a comprehensive model combining multiple brand associations aspects (rational and emotional) and their effects on customer loyalty. And finally, based on "Relational exchange theory" we aim to find out the mediation role of trust between brand associations and brand loyalty.

\section{Theoretical background}

\subsection{Business to business context and Industrial brand equity}


The industrial business context is characterized by unique features which distinguish it from $\mathrm{B} 2 \mathrm{C}$ context particularly with respect to purchasing process, characteristics of industrial business customer and factors influencing business buying behavior. First, the purchasing process usually go through a series of decision stages which begin from the recognition of the problem through the specifications development, vendors and product offerings identification and evaluation and the selection of one or more vendor, buying terms negotiation, performance evaluation, and the ongoing relationship management (Webster and Keller, 2004). Second, customers in B2B market differ from consumers in B2C context with respect to their purchases size, their buying power, the relationships nature they require from their suppliers in which the key roles in the decision making unit includes; initiators, users, influencers, buyer, gatekeeper and deciders. Further, one person may occupy several roles (Berger, 2016). Third, factors that affect the industrial business customer perspectives are multifaceted as it is affected by the type of product, organization characteristics, type of buying situation and purchase characteristics (uncertainty, complexity, time pressure and the importance of the purchase) (Berger, 2016).

Generally, industrial buying is viewed as a mixture of individual and organizational decision making processes, in which brands have influence on both processes as indicated by Webster and Keller (2004). The industrial brand can be regarded as an essential buyer decision making heuristic that helps in the building and development of trustworthy buyer-seller relationships (Marquardt, 2013). Moreover, branding in industrial context is essential as it augments the industrial brand equity through: first, cash flow benefits provision to companies and increased power of the network; second, enhancing the industrial brand's identity (Beverland et al., 2007). 
Industrial brand equity is defined as "customer/buyer perception of the overall industrial brand image, created through brand associations" (Bendixen et al., 2004; Michell et al., 2001). While, Alwi et al., (2016) define industrial brand equity as "a process of two psychological components: attitude and behavioral. The process begins with attitude, that is, brand association, referring to the performance of the brand (a tangible attribute), which in turn, helps to explain how the customer perceives the overall industrial brand image (an intangible association). This will then lead to trusting the brand (overall attitude component) and subsequently, result in a behavioral component, either brand loyalty and/or customer commitment".

Studies on industrial branding are classified into; first, studies that examines the relationships among the dimensions of brand equity (Biedenbach, 2012). Second, studies which examines the relationships between brand equity dimensions and antecedents (Cretu and Brodie, 2007; Roberts and Merrilees, 2007; Jensen and Klastrup, 2008; Marquardt, 2013; Zhang et al., 2015). Third, studies which empirically examine relationships between brand equity dimensions and consequences (Taylor et al. 2007; Davis et al. 2008). And finally, studies that examines the relationships among brand equity dimensions, antecedents and consequences (Van Riel et al. 2005; Han and Sung, 2008; Kim and Hyun, 2011; Alwi et al., 2016; Atashfaraz and Abadi, 2016; Sharma et al., 2016; Wu, 2014).

\subsection{Brand Associations and brand loyalty}

Brand association constitute part of brand knowledge in which Murtiasih et al., (2014) indicated that both brand awareness and brand associations represents 
"brand knowledge" (Yang and Ha, 2014). In this respect, brand associations represents the thoughts and feelings of customers' about a company (Bidenbach et al., 2011). More specifically, brand association is associated with brand information in the mind of customers either positive or negative which is linked to the brain memory node (Sasmita and Suki , 2015). Brand Association classification by Y.L. and Lee (2011) is consistent with Kuhn et al., (2008) study applied in the context of electronic tracking systems for waste management in which they classify brand associations into performance, imagery aspects and company aspects. Similarly, in the heating, ventilating and air-conditioning (HVAC) industry in Malaysia, Alwi et al. (2016) classify brand associations into brand performance and industrial brand image. Consequently, brand associations in B2B context are essential for brand equity enhancement (Bidenbach et al., 2011). Similarly, Kim and Hyun (2011) indicated that brand associations have strong direct influence on the brand equity overall value. In this respect, customers evaluations are based upon brand related attributes understanding in B2B context (Alwi et al., 2016). Consequently, brand associations in B2B context are essential for brand equity enhancement (Bidenbach et al., 2011). Similarly, Kim and Hyun (2011) indicated that brand associations have strong direct influence on the brand equity overall value. In this respect, customers evaluations are based upon brand related attributes understanding in B2B context (Alwi et al., 2016).

More recently, Rauyruen and Miller (2007, p. 23) particularize the definition of loyalty to the B2B case, distinguishing two types of loyalty. One is the behavior in which: "the willingness of average business customer to repurchase the service and the product of the service provider and to maintain a relationship with the service provider/supplier." The second is an attitude reflecting: "the level of customer's psychological attachments and attitudinal advocacy toward the service 
provider/supplier" (Janita and Miranda, 2013). The combinational method (composite approach) include both behavioral and attitudinal loyalty and thus considered as the most appropriate for the present study. As, the attitudinal approach concentrates on the cognitive process but neglects the actual buying behavior; on the contrary, the behavioral approach concentrates on the actual buying behavior but ignores the underlying cognitive process. Thus, to be loyal effectively, a customer should repurchase the brand, and also have a positive and favorable attitude towards it (Chuah et al., 2014). In the business-to-business relationship (B2B) customer loyalty has become one of the greatest concerns to researchers as increasing and securing current customer loyalty appears as an essential marketing issue due to the diverse advantages with respect to retaining current customers relative to searching for new or potential customers (AbdulRahman and Kamarulzaman, 2012).

\subsection{Research Gaps and the expected contribution}

Based on reviewing the literature, we generated some research gaps that need to be filled in future research. First, our knowledge of branding within industrial context still lags far behind our knowledge of branding in consumer context as most of research discussions have been developed in consumer context (Marquardt, 2013). In this respect, research to this extent in $\mathrm{B} 2 \mathrm{~B}$ context has revealed mixed results with respect to industrial brand equity composition and drivers (Leek and christodoulides, 2012). As such, there is no existence of a comprehensive B2B brand model (Johansen, 2009). Thus, B2B branding extant literature remains fragmented, and further examination for areas with limited or inconclusive research is needed (Zhang et al., 2015). In particular, the branding of future-based and uncertain industrial products which represents hybrid offerings involving 
aspects of both goods and services needs further research examination (Marquardt, 2013).

Second, despite brand associations importance, the role of specific brand associations in liberalized energy brands is still to a large extent largely undetermined (Hartmann and Ibanez, 2007) as it have been ignored in the literature of marketing (Wang et al , 2008) and thus under researched (Alwi et al. 2016).

Third, most industrial branding cannot address aspects at the corporate brand level as it portrays the brand at product level (Webster and Keller, 2004) in which the frameworks put forward particularly by Mudambi et al. (1997) and Kuhn et al. (2008) consider the brand performance attributes, however, neither of them integrates the emotional attributes. As such, previous studies over rely on tangible and rational attributes which alone cannot explain fully the logic behind purchase decisions in B2B context as not only tangible attributes is evaluated but also intangible features. In this respect, the corporate image should be given an attention in future research (Alwi et al. 2016). Thus, the present study also explored industrial brands by incorporating elements of industrial brand image.

Moreover, trust with the company/brand which is viewed as an essential source of brand equity and an emotional brand element (Ambler, 1997) is scarcely investigated except for Han and Sung's (2008) study. Also, there exists inconsistent opinions with respect to identifying trust as part or separate to concept of brand equity (Ambler, 1997).

\subsection{Brand performance and brand loyalty}


The Social exchange theory posits that firms establish long-term relationships with suppliers that provide value which exceeds the value offerings of their competitors (Blau, 1964). Thus, outperforming rivals on criteria of supply source selection becomes essential for supplier companies in order to establish relational exchanges that are enduring with their counterparts. Hence, drawing upon this theory, it can be argued that customers' perceptions of supplier brand performance in (product, service quality and price) influence the credibility of the supplier in the eyes of the customer, which in turn serves as a platform for purchasing firms to engage in ongoing business exchanges with supplying companies.

Brand performance in the present study is conceptualized as tangible, functional and rational brand attributes in which brand performance is measured by product, service quality and price dimensions. With respect to product quality, Ulaga (2003) define product quality as "the extent to which the supplier's product meets the customer's specification”. In the heating, ventilating and air-conditioning (HVAC) B2B industry in Malaysia. Alwi et al., (2016) measure product quality as the extent to which company product brand is a; reliable, durable, consistent in quality and is synonym to high-quality product in overall. In B2B context, Cater and Cater (2010) study results show that product quality affects directly attitudinal and behavioral loyalty. Another important brand performance dimension is service quality. In the context of liberalized energy market, Hartmann and Ibanez (2007) noted that service quality associations are viewed as a critical element of the brand's promise in which Gronroos (1984) defines customers' service quality associations as "the result of the perceptions of what they get (technical service quality) and how they get it (service process quality)". In this respect, Hartmann and Ibanez (2007) mentioned that technical service quality reflects both the energy supply (core service technical quality), i.e. reliability of energy supply, and 
(peripheral services technical quality), i.e. information about energy saving, maintenance, adaptable contracts, etc. On the other hand, Perceived service process, reflects employee interaction with customers, e.g. promptness of service, , politeness, courtesy, etc. In a service context, several studies reveals a positive relationship between service quality and loyalty (Rasheed and Abadi, 2014; Giovanis et al. 2014; Bidenbach et al. 2011). In a business context, many studies support the direct positive relationship between service quality and loyalty (|Van Riel et al. , 2005; Kim and Hyun, 2011).

In the context of liberalized energy market, Hartmann and Ibanez (2007) mentioned that perceptions of price can be viewed an important factor in determining the perceived value of energy brand in which customers use such information regarding price in assessing the monetary sacrifice of the purchase so that customers make a trade-off between their monetary benefit and sacrifice to determine brand value. Several studies indicates the positive effect of reasonable pricing on loyalty in B2B context ( Alwi et al., 2016; Williams et al., 2011; Kim and Hyun, 2011). Hence, it is hypothesized that:

H1: Product quality is positively associated with loyalty

H2: Service quality is positively associated with loyalty

H3: Reasonably priced is positively associated with loyalty

\subsection{Industrial brand image and brand loyalty}

Drawing upon the Social exchange theory, it can be argued that customers' perceptions of supplier brand image in (innovation, environmental and social commitment, value added service technology excellence and trust) influence the credibility of the supplier in the eyes of the customer, which in turn serves as a 
platform for purchasing firms to engage in ongoing business exchanges with supplying companies.

Brand equity arising from brand image is more important in situations where product differentiation is difficult based upon tangible attributes, industrial brand image is concerned with the overall attitude or intangible (emotional) attributes of the brand which is essential as it guide firms to its brand positioning and sustainable differential advantage in the B2B context (Alwi et al. 2016). Industrial brand image in the present study is measured by innovation, corporate social responsibility, value added services and technology excellence. With regard to innovation dimension, Alwi et al. (2016) mentioned that innovation allow firms to detect a source of brand differentiation in their branding strategies thus, innovation capability allow firms to build brand equity (loyalty) through providing differentiated product or service offerings, communicating corporate image that is attractive to customers and designing appealing marketing program (Zhang et al. 2015).

Also, Hartmann and Ibanez (2007) noted that offering green energy products witness a pivotal importance worldwide in energy markets (Hartmann and Ibanez, 2007). Moreover, Arikan and Guner (2013) indicated that the socially responsible behavior perception reinforce commitment toward the firm in which customers are more motivated to purchase products from firms participating in corporate social responsibility (CSR) aspects as these efforts are valued highly by customers and thus increase customers loyalty toward the firm.

In the context of liberalized energy market, Hartmann and Ibanez (2007) noted that most energy service brands today are adding an increasing range of value-added 
services to their portfolio, such as insurance and financing services, telecommunications and online customer interaction, etc. The main strategy behind value-added services is to change customer perception regarding the energy supplier, as several suppliers aims to be perceived as multi-service brands, which supply the whole products and services customers need in which value added services strategy is based upon relating the customer to the company through offering a wide range of products and services, which results in less price comparisons and thus, decreasing the chance that a customer will switch to another suppliers. In this respect, Janita and Miranda (2013) study applied in e-marketplace context findings indicates that value-added services is a determinant of its clients' loyalty.

Research reveals that positive responses of customers to new technology increase overall value of the firm (Lee \& Grewal, 2004). In display technology context, Lin et al. (2015) study found that easy to use is essential for improving customers' loyalty. Hence, based on the above discussion, we posit that:

H4: Innovation is positively associated with loyalty

H5: Corporate social responsibility influences loyalty H6:Value-added service positively influences loyalty.

H7: Technology - excellence positively influence loyalty

\subsection{The mediation role of trust between brand associations and brand loyalty}

Kundu and Datta (2015) noted that the conceptualization of trust differ based upon context of study. For instance, in the B2B context, Alwi et al. (2016) study applied in heating, ventilating and air-conditioning (HVAC) industry in Malaysia noted that brand trust concerns the supplier capability in promises fulfillment and preserving consistency in the performance of product and service. 
In this respect, trust is viewed as value which is emotional in nature emanating from the affective state produced by product or service. In this sense, Chuah et al (2014) mentioned that emotional value reflects the utility originated from the affective states whih is generated by a product or service. The emotional bonds between customers and companies are very complex to be imitated by competitors. Thus, firms today are struggling for the achievement of sustainable competitive advantage through adding emotional value to their core offerings (Chuah et al , 2014). Moreover, linking a service brand with trust improves brand value perception through decreasing customer cognitive effort associated with worrying about whether or not a supplier will satisfy customer needs and meet their promises (Hartmann and Ibanez, 2007) specifically, in situations where there exist high perceived risk (Phan and Ghantous, 2013).

Significantly, in the context of liberalized energy market, Hartmann and Ibanez (2007) noted that the feeling of trust towards the energy brand is expected to enhance customer loyalty as trust feeling is anticipated to appear after a long period of consumption with respect to the same energy brand in which their study findings revealed that brand trust has a strong impact on customer loyalty. In the context of heating, ventilating and air-conditioning (HVAC) B2B industry in Malaysia, Alwi et al. (2016) examine brand trust concept centrality between brand associations (tangible and intangible associations) and brand equity's outcome (such as brand loyalty), in which their study findings reveals that brand trust is a strong mediator between brand associations and brand loyalty. Thus, the present research posits;

H8: Trust positively influence brand loyalty 
H9: Trust is a mediator between a) product quality, b) service quality, c) Price, d) innovation, e) Corporate social responsibility, f) Value-added services, and g) Technology-excellence AND Loyalty. Based on the previous research hypotheses, the relationships among the research constructs are illustrated in Figure (1) below;

Figure (1): The conceptual Model

\section{Brand Associations}

Brand performance

- Product Quality

- Service quality

- Price

Industrial Brand image

- Innovation

- Corporate Social Responsibility

- Value-added services

- Technologyexcellence

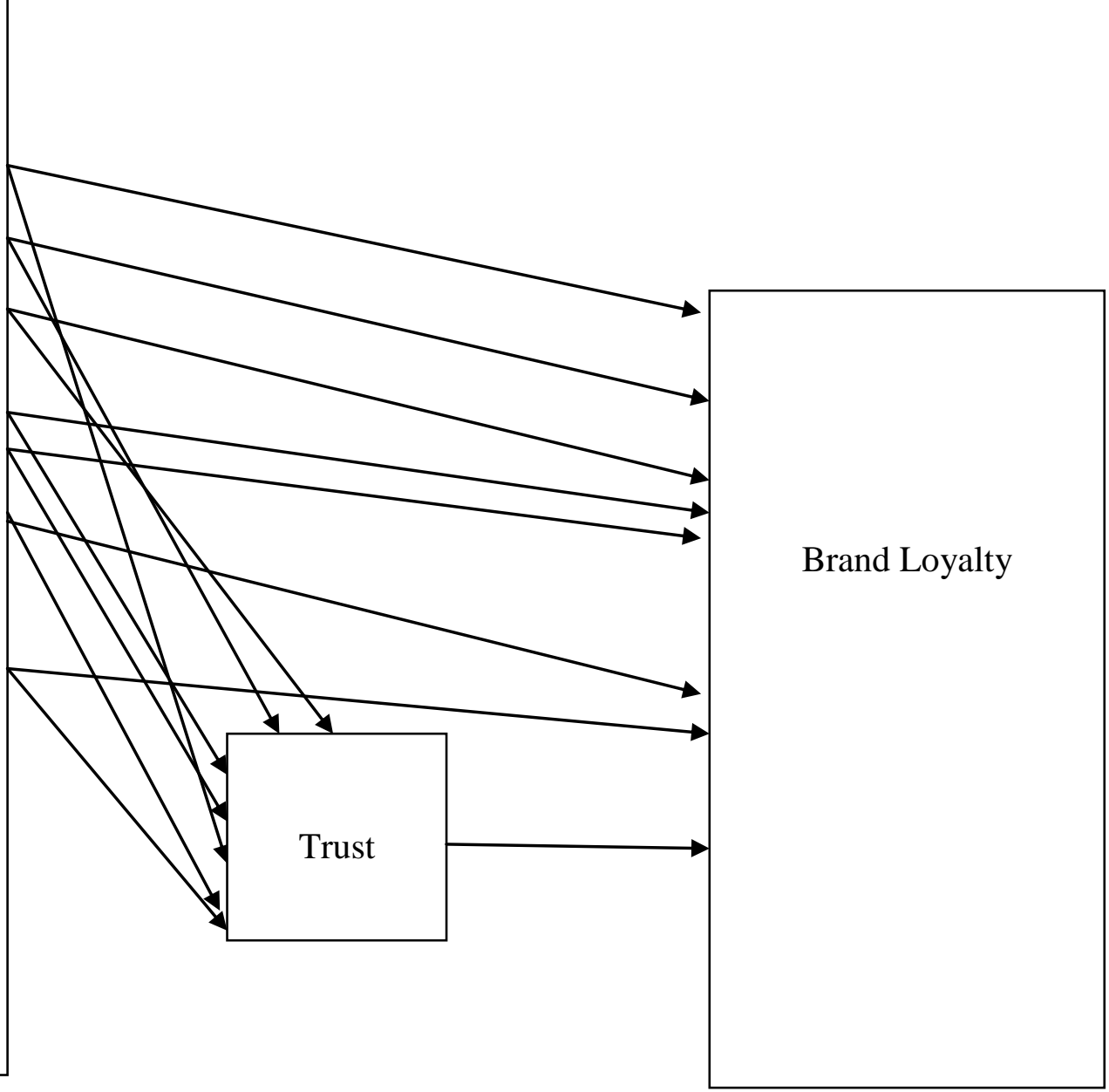

\section{Proposed Research Methodology}

This study will be applied on customer companies operating in the joint sector as companies in this sector deals extensively with private suppliers than other sectors 
in the petroleum field. First, we will conduct some qualitative work to explore the brand associations that would allow for successful industrial brand positioning for the private suppliers and which inurn contribute to joint sector companies loyalty via in-depth interviews with engineers, accountants, geologists and consultants using semi-structured questionnaires as they represents the key decision makers (key informants) in the buying center who are responsible for evaluating and choosing the private Egyptian supplier company with whom the customer company is going to deal with. Then, the quantitative approach will follow the exploratory phase to conclude the results and generalize them via multi-crosssectional survey using structured questionnaire. A convenience non probability sample will be employed taking into consideration percentage of specialization for engineers, accountants and geologists. Finally, the researchers may conduct some qualitative follow up work with those who were asked in the exploratory research to get more insights of the research results. 


\section{References}

Alwi S.F.S. et al., (2016), "Explicating industrial brand equity Integrating brand trust, brand performance and industrial brand image", Industrial Management \& Data Systems, Vol. 116 , No. 5, pp. 858-882.

Atashfaraz M. and Abadi M.H.H.S. (2016) , Impact Of E-Service Innovation On Brand Equality And Customer Loyalty In Samsung International Corporation, Procedia Economics and Finance, 36,PP. $327-335$.

Abdul-Rahmana M. and Kamarulzaman Y. (2012), The influence of relationship quality and switching costs on customer Loyalty in the Malaysian Hotel Industry, Procedia - Social and Behavioral Sciences, Vol. 62, PP. 1023 - 1027.

Ambler, T. (1997), "How much of brand equity is explained by trust?", Management Decision, Vol. 35 No. 4, pp. 283-292.

Arikan E. and Guner S. (2013), The impact of corporate social responsibility, service quality and customer- company identification on customers, Procedia - Social and Behavioral Sciences, Vol. 99, PP. $304-313$.

Beverland, M., Napoli, J. and Yakimova, R. (2007), "Branding the business marketing offer: exploring brand attributes in business markets", Journal of Business and Industrial Marketing, Vol. 22 No. 6, pp. 394-399.

Blau, P. M. 1964. Exchange and power in social life. New York: John Wiley

Biedenbach G. (2012), "Brand equity in the business-to business context: Examining the structural composition", Journal of Brand Management, Vol. 19, No.8, PP. 688-701. 
Biedenbach, G., Bengtsson, M., \& Wincent, J. (2011), Brand equity in the professional service context: Analyzing the impact of employee role behavior and customer- employee rapport. Industrial Marketing Management, 40(7), 1093-1102.

Berger PH. (2016), " An Exploration of Customer-Based Brand Equity in Industrial Markets", PHD thesis, The University of Gloucestershire.

Bendixen , M ., Bukasa , K . A . and Abratt , R . ( 2004 ), " Brand equity in the business-tobusiness market", Industrial Marketing Management, 33 (5), PP. 371 - 380 .

Cater T. and Cater B. (2010), "Product and relationship quality influence on customer commitment and loyalty in B2B manufacturing relationships", Industrial Marketing Management , Vol.39, PP.1321-1333.

Chi-Shiun, L., Chih-Jen, C., Chin-Fang, Y. and Da-Chang, P. (2010), "The effects of corporate social responsibility on brand performance: the mediating effect of industrial brand equity and corporate reputation", Journal of Business Ethics, Vol. 95 No. 3, pp. 457-469.

Cretu, A. E., \& Brodie, R. J. (2007), The influence of brand image and company reputation where manufacturers market to small firms: A customer value perspective, Industrial Marketing Management, 36(2), 230-240.

Chuah H. W. et al., (2014), "The Effect of Perceived Value on the Loyalty of Generation Y Mobile Internet Subscribers: A Proposed Conceptual Framework", Procedia - Social and Behavioral Sciences, Vol. 130, PP. $532-541$.

Davis , D . F ., Golicic , S . L . and Marquardt , A . J . ( 2008 ), Branding a B2B service: Does a brand differentiate a logistics service provider, Industrial Marketing Management, 37 (2) : 218 227 . 
Grönroos, Christian (1984). A service quality model and its marketing implications. European Journal of Marketing, 18(4), 37-44.

Giovanis A. N. et al. (2014), The antecedents of customer loyalty for broadband services: The role of service quality, emotional satisfaction and corporate image, Procedia - Social and Behavioral Sciences, Vol.148, PP. $236-244$.

Hartmann P. and Ibanez V.A., (2007). " Managing customer loyalty in liberalized residential energy markets: The impact of energy branding". Energy Policy, Vol. 35 , PP. 2661-2672.

Han, S. L., \& Sung, H. S. (2008). Industrial brand value and relationship performance in business markets-A general structural equation model. Industrial Marketing Management, 37(7), 807-818.

Jensen, M. B., \& Klastrup, K. (2008). Towards a B2B customer-based brand equity model. Journal of Targeting, Measurement and Analysis for Marketing, 16(2), 122-128.

Janita M. S. and Miranda F.J. (2013), The antecedents of client loyalty in business-to-business (B2B) electronic marketplaces, Industrial Marketing Management, Vol. 42 , PP. 814-823.

Johansen B. (2009), "Brand Management in the Energy Sector: a means end approach to identify and build sources to brand equity in a B2B green energy context in Norway", Master Thesis, Copenhagen Business School.

Kim J.H. and Hyun Y.J. (2011), "A model to investigate the influence of marketing-mix efforts and corporate image on brand equity in the IT software sector", Industrial Marketing Management, Vol. 40,PP. 424-438.

Kuhn, K. A. L., Alpert, F., \& Pope, N. K. L. (2008). An application of Keller's brand equity model in a B2B context. Qualitative Market Research: An International Journal, 11(1), 40-58. 
Kundu S. and Datta S. K. (2015), "Impact of trust on the relationship of e-service quality and customer satisfaction", EuroMed Journal of Business, Vol. 10, Iss 1, pp. 21 - 46.

Leek S. and Christodoulides G. (2012), "A framework of brand value in B2B markets: The contributing role of functional and emotional components", Industrial Marketing Management,Vol. 41 , PP. 106-114.

Lee, R.P., \& Grewal, R. (2004). Strategic responses to new technologies and their impact on firm performance. Journal of Marketing, 68(4), 157-171.

Lin C.H. et al. (2015), The empirical study of consumers' loyalty for display technology, Journal of Business Research, Vol. 68 , PP. 2260-2265.

Marquardt A.J. (2013), "Relationship quality as a resource to build industrial brand equity when products are uncertain and future-based", Industrial Marketing Management, Vol. 42, PP. 13861397.

Michell, P., King, J., \& Reast, J. (2001). Brand values related to industrial products. Industrial Marketing Management, 30(5), 415-425.

Murtiasih S., et al. (2014),"Impact of country of origin and word of mouth on brand equity". Marketing Intelligence \& Planning. Vol. 32, Iss 5, pp. 616-629.

Mudambi, S.M., Doyle, P. and Wong, V. (1997), “An exploration of branding in industrial market”, Industrial Marketing Management, Vol. 26 No. 5, pp. 433-446.

Roberts , J . and Merrilees , B . ( 2007 ), Multiple roles of brands in business-to-business services , Journal of Business \& Industrial Marketing, Vol.22 (6), 410 - 417 .

Rauyruen, P., \& Miller, Kenneth E. (2007). Relationship quality as a predictor of B2B customer loyalty. Journal of Business Research, 60(1), 21-31. 
Rasheed F.A. and Abadi M. F. (2014), Impact of service quality, trust and perceived value on customer loyalty in Malaysia services industries, Procedia - Social and Behavioral Sciences, Vol. 164, PP. $298-304$.

Phan K. N. and Ghantous N. (2013), "Managing brand associations to drive customers' trust and loyalty in Vietnamese banking", International Journal of Bank Marketing, Vol. 31, Iss 6, pp. 456 -480 .

Sharma P. et al., (2016), " Product innovation as a mediator in the impact of R\&D expenditure and brand equity on marketing performance", Journal of Business Research.

Sasmita J. and Suki N. M., (2015),"Young consumers' insights on brand equity", International Journal of Retail \& Distribution Management, Vol. 43, Iss 3, pp. 276 - 292.

Taylor, S . A ., Hunter, G . L . and Lindberg, D . L . ( 2007 ), Understanding (customer-based) brand equity in fi nancial services, Journal of Services Marketing 21 (4), $241-252$.

Ulaga, W. (2003), Capturing value creation in business relationships: A customer perspective, Industrial Marketing Management, 32(8), 677-693.

Van Riel , A . C . R ., de Mortanges, C . P . and Streukens , S . ( 2005 )," Marketing antecedents of industrial brand equity: An empirical investigation in specialty chemicals" , Industrial Marketing Management, 34 (8), $841-847$.

Wang H. et al., (2008),"Global brand equity model: combining customer-based with productmarket outcome approaches", Journal of Product \& Brand Management, Vol. 17, Iss 5, pp. 305 316.

Wang L. and Finn A. , (2014),"A cross-product category CBBE study: item response theory perspective", Journal of Product \& Brand Management, Vol. 23, Iss 3, pp. 200 - 206. 
Williams P. et al. (2011),Customer attitudes of stayers and defectors in B2B services: Are they really different?, Industrial Marketing Management, Vol. 40 , PP. 805-815.

Webster F.E. and Keller K.L. (2004), "A roadmap for branding in industrial markets", BRAND MANAGEMENT, VOL. 11, NO. 5, PP. 388-402.

Wu C. W. (2014), "The study of service innovation for digiservice on loyalty", Journal of Business Research, Vol. 67, PP. 819-824.

Yang S. and Ha S., (2014),"Brand knowledge transfer via sponsorship in the financial services industry", Journal of Services Marketing, Vol. 28, Iss 6, pp. $452-459$.

Y.L.F. and Lee G.C. (2011), "Customer-based brand equity: A literature review", Journal of Arts Science and Commerce, Vol.11, Iss 1.

Zhang J. et al., (2015), "Building industrial brand equity by leveraging firm capabilities and co-creating value with customers", Industrial Marketing Management, Vol. 51, PP. 47-58. 